\title{
Seismic Performance of High Rise Flat Slab Building with Various Lateral Load Resisting Systems
}

\author{
Pooja Biradar, Kishor Kulkarni and Nikhil Jamble
}

\begin{abstract}
In modern era, the construction of flat slab building is increasing everywhere, due to its major advantages such as architectural flexibility and lesser cost of construction .The use of flat slab in high seismic area is a risk as it is not efficient in resisting lateral loads. The study is considered about increase in lateral load carrying capacity of building by using shear walls, perimeter beams and bracing system. In this study 15 storied flat slab building is analyzed for different lateral load resisting system using time history method. For the time history method, realistic BHUJ earthquake data is used and analysis is carried out by commercially available software 'ETABs $v 9 i$ '. The comparison of different lateral load resisting system (LLRS) is made by using various parameter such as maximum storey displacement, storey drift, time period and base shear.
\end{abstract}

Keywords--- Flat Slab, Shears Wall, Bracings, Mode Shapes.

\section{INTRODUCTION}

I NDIA is a developing country and there is a huge growth in infrastructure development. As the population of India is increasing day by day there is high demand of land for construction. Since, most of the land is preserved for agriculture and farming, there is need for space for human dwelling hence development in vertical construction is necessary. Nowadays there is increase in number of tall buildings which are used for both commercial and residential purposes. When the height of the building increases it is important to counteract the lateral forces such as seismic and wind forces acting on the building. Normally the buildings are designed to counteract the gravity loads acting on it and to attain required strength and stability. Usually buildings are designed to resist gravity loads such as dead loads and live loads but other than these other loads acting laterally on the building such as earthquake and wind loads which may also act on it. To resist these lateral loads extra Lateral Load Resisting System (LLRS) is to be included in tall buildings. Lateral loads can develop high stresses and large lateral displacement. Therefore, it is very important for the structure to have adequate stiffness to resist lateral force along with strength to resist gravity loads. In modern era, along with the

Pooja Biradar, Student, Structural Engineering, KLEMSSCET, Belagavi, Karnataka, India. E-mail:pgbiradar93@gmail.com

Kishor Kulkarni, Assistant Professor, Dept. of Civil Engg, KLEMSSCET, Belagavi, Karnataka, India.E-mail:kishorsk1@gmail.com

Nikhil Jamble, Assistant Professor, Dept. of Civil Engg, KLEMSSCET, Belagavi, Karnataka, India.

DOI:10.9756/BIJMMI.8151 construction of high rise building there is also need to emphasis on the aesthetic view of the building and lesser cost of construction along with architectural flexibility. Hence modern trend is to construct high rise building with flat slab floor system. [1].

\section{STRUCTURAL MODELING AND ANALYSIS}

In the present study multistoried building with flat slab system is modeled and analyzed for seismic forces. The various parameters are considered to make it seismic resistance. The different locations of shear wall at different locations and combination of bracing and shear wall system. 8 models are considered for the study. The whole analysis is carried out using commercially available software 'ETABS' 9 vi. The details of multistoried flat slab building are given in Table 2.1.

Table 1: Details of Multistoried Flat Slab Building

\begin{tabular}{|l|l|}
\hline Type of building & Commercial building \\
\hline Plan area & $35 \mathrm{mX} 35 \mathrm{~m}$ \\
\hline Storey height & $3.75 \mathrm{~m}$ \\
\hline Total height of building & $54.5 \mathrm{~m}$ \\
\hline Bays & $\begin{array}{l}5 \text { bays in both X and } \\
\text { Y-direction }\end{array}$ \\
\hline Spacing of bays & $7 \mathrm{~m}$ \\
\hline Type of soil & Type II( Medium soil) \\
\hline Earthquake zone & III \\
\hline Location of building & Pune \\
\hline
\end{tabular}

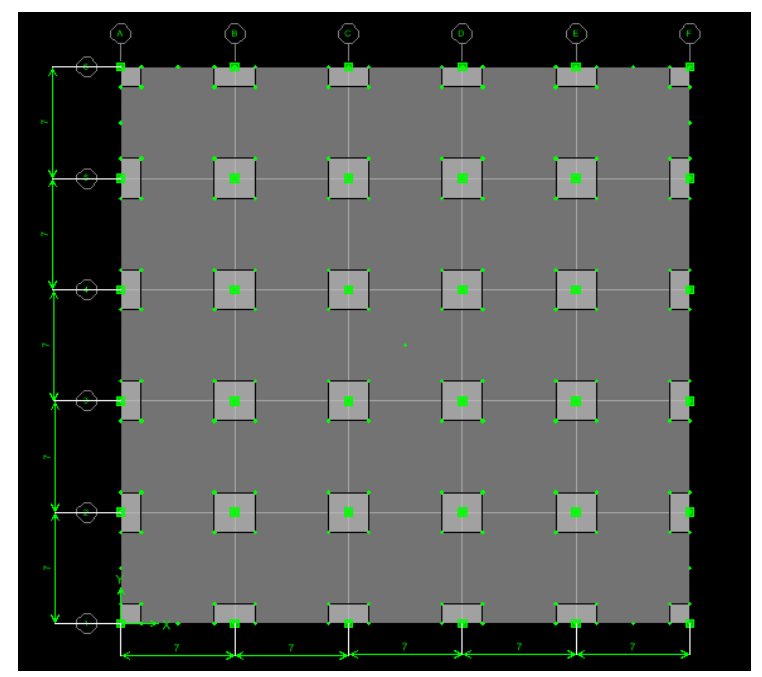

Figure 1: Plan of the RC Flat Slab Building 
The properties of the material taken in the analysis and the details of gravity and seismic loadings are presented in Table 2.

Table 2: Material Properties and Loadings

\begin{tabular}{|l|l|}
\hline Grade of concrete & $\mathrm{M} 25$ \\
\hline Density of concrete & $25 \mathrm{kN} / \mathrm{m}^{3}$ \\
\hline Grade of steel reinforcement & $\mathrm{Fe} 415$ \\
\hline Grade of steel bracings & $\mathrm{Fe} 250$ \\
\hline Live load & $3 \mathrm{kN} / \mathrm{m} 2$ \\
\hline Floors finish & $1.5 \mathrm{kN} / \mathrm{m}^{2}$ \\
\hline Live load reduction factor & $25 \%$ \\
\hline Seismic zone factor & 0.16 \\
\hline Response reduction factor & 5 \\
\hline Importance factor & 1 \\
\hline
\end{tabular}

The dimensions of the structural members are designed as per code IS 456:2002 ${ }^{7}$ and are presented in Table 3.The flat slab and drop of the building considered for the analysis are designed for gravity loads as per code IS $456: 2002^{7}$ and the thickness of flat slab and drop are adopted as per the design. The dimensions of structural members are given.

Table 3: Details of Structural Members

\begin{tabular}{|l|l|}
\hline Slab thickness & $0.2 \mathrm{~m}$ \\
\hline Drop thickness & $0.1 \mathrm{~m}$ \\
\hline Diaphragm & Rigid \\
\hline
\end{tabular}

The building is analyzed for the gravity loads and the column size is fixed based on the analysis. The size of column for different stories is give in table 4

Table 4: Column Dimensions

\begin{tabular}{|l|l|}
\hline $1^{\text {st }}$ storey & $1.2 \mathrm{mx} 1.2 \mathrm{~m}$ \\
\hline $2^{\text {nd }}$ to $3^{\text {rd }}$ storey & $1 \mathrm{mx} 1 \mathrm{~m}$ \\
\hline $4^{\text {th }}$ to $6^{\text {th }}$ storey & $0.9 \mathrm{mx} 0.9 \mathrm{~m}$ \\
\hline $7^{\text {th }}$ to $8^{\text {th }}$ storey & $0.75 \mathrm{mx} 0.75 \mathrm{~m}$ \\
\hline $9^{\text {th }}$ to $15^{\text {th }}$ storey & $0.68 \mathrm{mx} 0.68 \mathrm{~m}$ \\
\hline
\end{tabular}

Table 5: Description of Various Models Used

\begin{tabular}{|l|l|}
\hline Description & Notations \\
\hline Flat slab building & $\mathrm{BF}$ \\
\hline Flat slab building with centre shear wall & $\mathrm{CnSW}$ \\
\hline Flat slab building with corner shear wall & $\mathrm{CrSW}$ \\
\hline Flat slab building with parallel shear wall & $\mathrm{PSW}$ \\
\hline Flat slab building with centre and parallel shear wall & $\mathrm{CnPSW}$ \\
\hline Flat slab building with centre and corner shear wall & $\mathrm{CnCrSW}$ \\
\hline Flat slab building with centre shear wall and perimeter beams & $\mathrm{CnSWPb}$ \\
\hline Flat slab building with bracings at exterior and centre shear wall & $\mathrm{CnSWEb}$ \\
\hline
\end{tabular}

Model 1 is the flat slab building with bare frame. Model 2 consists of flat slab building with channel shaped centre shear wall only. The plan of building with different locations of shear wall is shown in Fig 2. The thickness of shear wall is assumed to be $0.3 \mathrm{~m}$. Model 6 consists of flat slab building with centre shear wall and perimeter beams. The length of shear wall is taken to be $6 \mathrm{~m}$ in one direction. The model 7 considered for the analysis consists of centre shear wall and exterior bracing. Bracings considered are the channel sections.
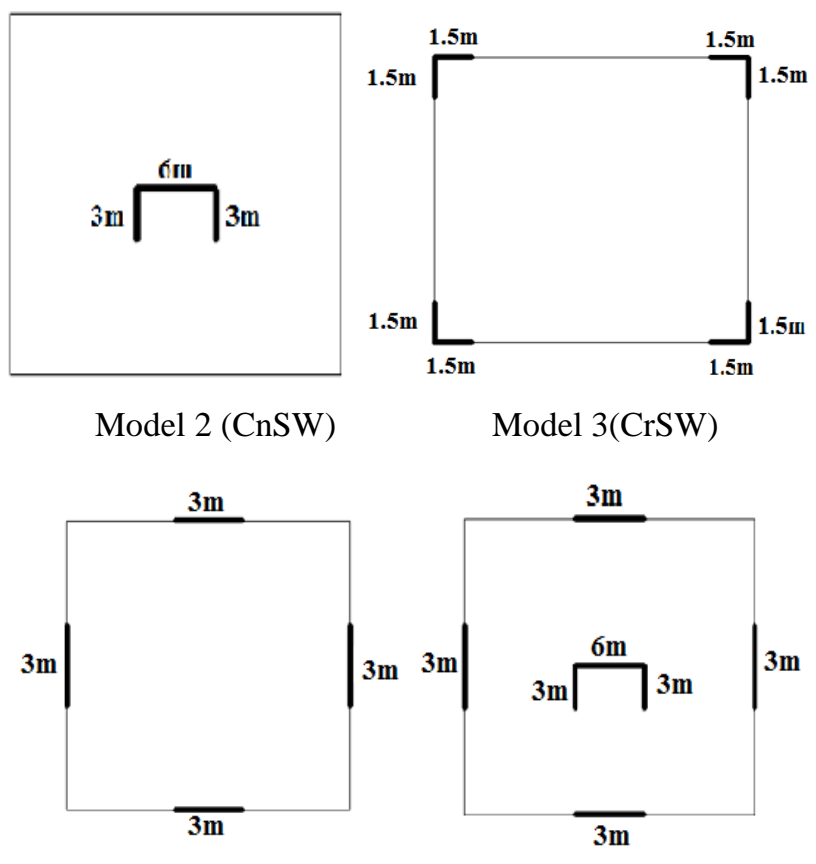

Model 4 (PSW)

Model 5 (CrPSW)

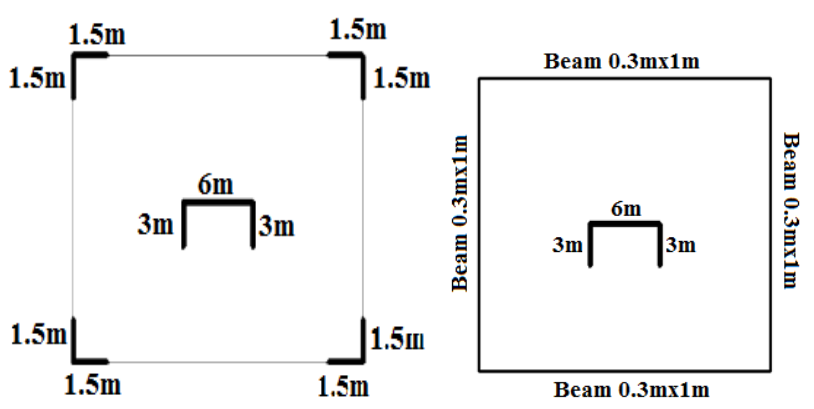

Model 6 (CrCnSW) Model 7 (CrSWPb)

Figure 2: Plan of Various Models Used

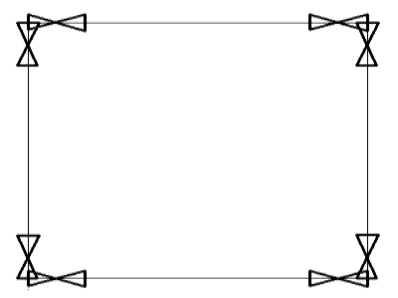

Figure 3: Position of Bracings in Flat Slab Building With $\mathrm{CnSWEb}$

\section{A. Seismic Analysis}

The seismic analysis of the RC flat slab Multistoried building is carried out by linear time history method is used to determine the design lateral load. Among the equivalent static, response spectrum and time history method of seismic analysis of the building the time History method is taken as most accurate method as it considers the realistic earthquake data for the analysis. In this study the 'Bhuj' earthquake data is used for the time history analysis 


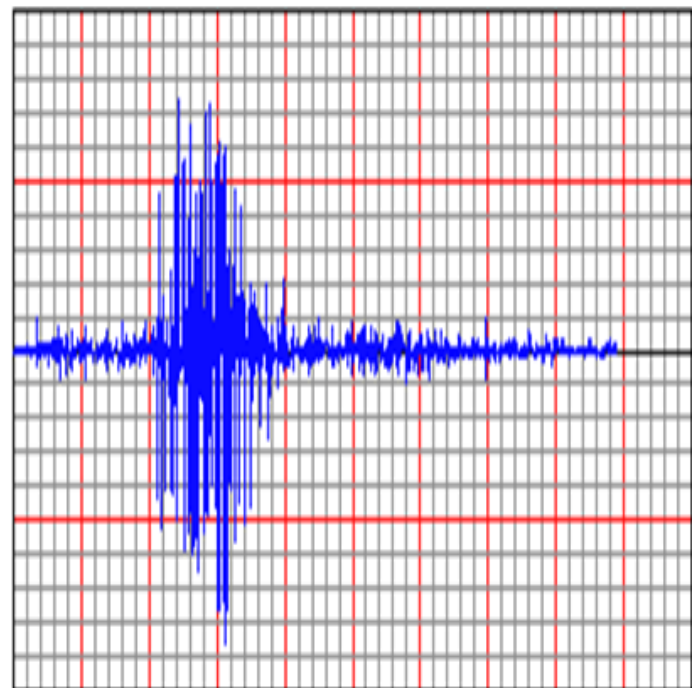

Figure 4: Time History Plot of Bhuj Earthquake

\section{RESULTS AND DISCUSSION}

This section presents the results on seismic performance of high rise flat slab RC structure subjected to lateral force for various lateral load resisting systems. The results are presented in the form of storey displacement, storey drift, time period and base shear with respect to various LLRS. A comparison is also carried out between bare frame and various lateral load resisting systems.

\section{A. Storey Displacement}

Storey displacement is found to be maximum for top stories where as the displacement goes on reducing for bottom stories. The results of storey displacement for various LLRS in $\mathrm{X}$-direction and $\mathrm{Y}$-direction. The variation in storey displacement with different LLRS are plotted in Fig 4 and Fig 5 .

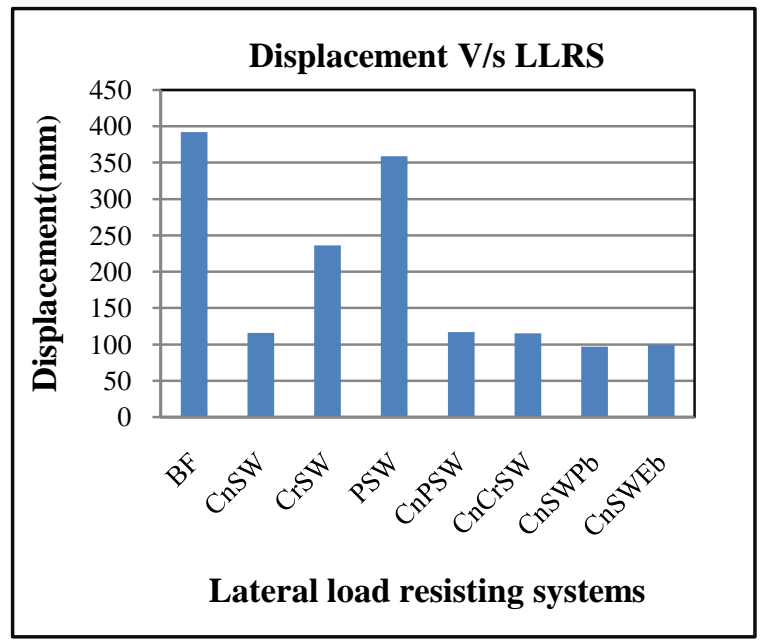

Figure 5: Storey Displacement in X-direction V/s LLRS

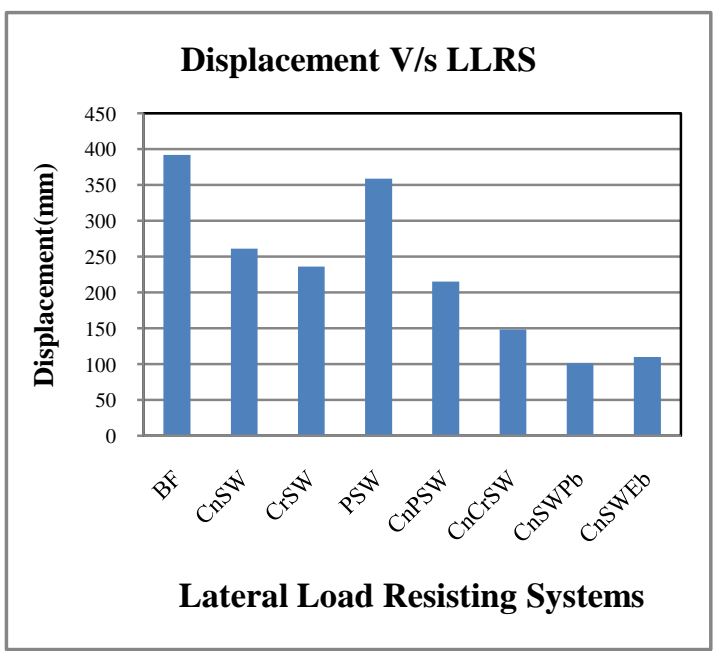

Figure 6: Storey Displacement in Y-Direction V/s LLRS

The reduction in the storey displacement in $\mathrm{Y}$ direction is about $33 \%, 39 \%, 8 \%, 45 \%, 62 \%, 74 \%$ and $72 \%$ for $\mathrm{CnSW}$, $\mathrm{CrSW}$, PSW, CnPSW, CnCrSW, CnSWPb and $\mathrm{CnSWEb}$ respectively, as compared to bare frame. There is marginal change in storey displacement for $\mathrm{CnSW}$ and CnPSW lateral load resisting system as compared with $\mathrm{X}$ direction displacement. This is due to the presence of channel shaped shear wall placed at centre of the building which do not provide the adequate stiffness for resisting lateral forces in Y-direction Amongst all the LLRS centre shear wall with perimeter beam and centre shear wall with exterior bracing shown better performance under seismic force when compared to bare frame. This is probably due to, increase in stiffness of $\mathrm{RC}$ building, which helps in considerably reduction of lateral displacement under seismic force.

\section{B. Storey Drift}

The results of storey drift for various LLRS in $\mathrm{X}$ and $\mathrm{Y}$ direction with different LLRS is plotted in Fig 6 and Fig 7.

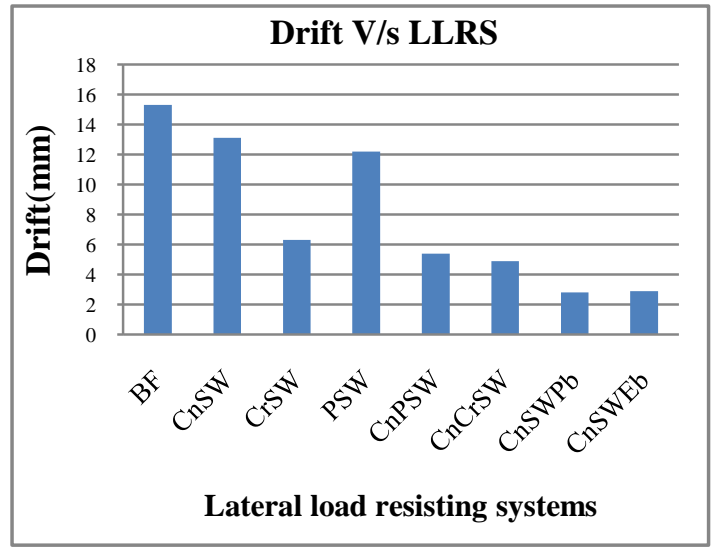

Figure 7: Storey Drift in X-Direction V/s LLRS 


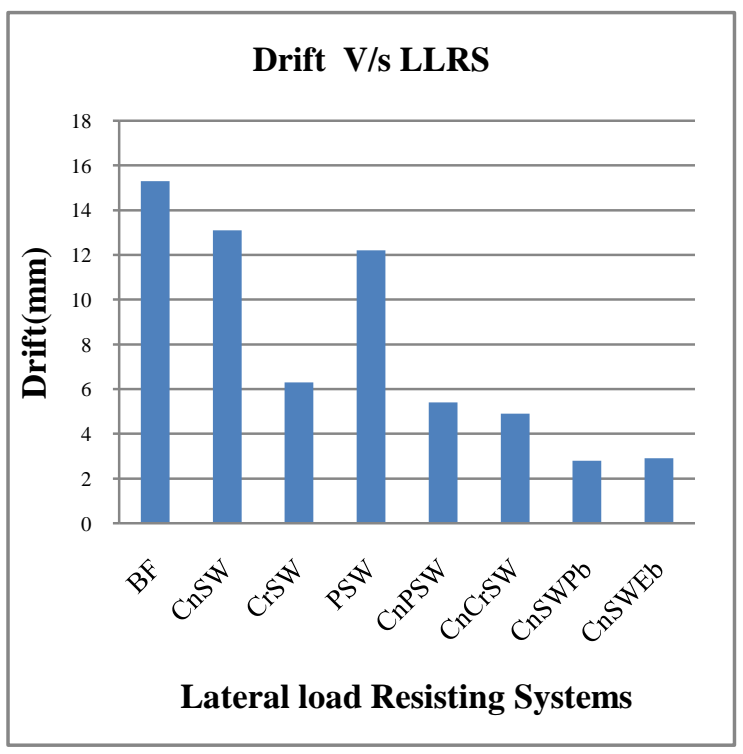

Figure 8: Storey Drift in Y-Direction V/s LLRS

The reduction in drift in X-direction is about $57 \%, 58 \%$, $20 \%, 75 \%, 77 \%, 83 \%$ and $82 \%$ for $\mathrm{CnSW}, \mathrm{CrSW}, \mathrm{PSW}$, $\mathrm{CnPSW}, \mathrm{CnCrSW}, \mathrm{CnSWPb}$ and $\mathrm{CnSWEb}$ respectively as compared to bare frame. Amongst all the LLRS centre shear wall with perimeter beam and centre shear wall with exterior bracing shown better performance under seismic force. The reduction in displacement is mainly due to presence of beams and bracings in the building. As the presence of perimeter beam and bracings in the model $\mathrm{CnSWPb}$ and $\mathrm{CnSWEb}$ respectively increases the stiffness of the building there is considerable reduction in drift when compared to bare frame under seismic effects.

The reduction in drift value in $\mathrm{Y}$ direction is about $26 \%$, $58 \%, 20 \%, 64 \%, 68 \%, 82 \%, 81 \%$, for $\mathrm{CnSW}, \mathrm{CrSW}, \mathrm{CnPSW}$, $\mathrm{CnCrSW}, \mathrm{CnSWPb}$, and $\mathrm{CnSWEb}$ respectively as compared to bare frame. Amongst all the LLRS centre shear wall with perimeter beam and centre shear wall with exterior bracing shown better performance under seismic force. There is a marginal increase in storey drift for model $\mathrm{CnSW}$ and CnPSW compared to $\mathrm{X}$ direction drift values. This may be due to the presence of channel shaped shear wall in the centre of the building which makes the storey drift more in the $\mathrm{Y}$ direction.

\section{B. Natural Period}

Fundamental natural period is first longest modal time period of vibration. The results of natural time period for various LLRS are presented in Fig 8.

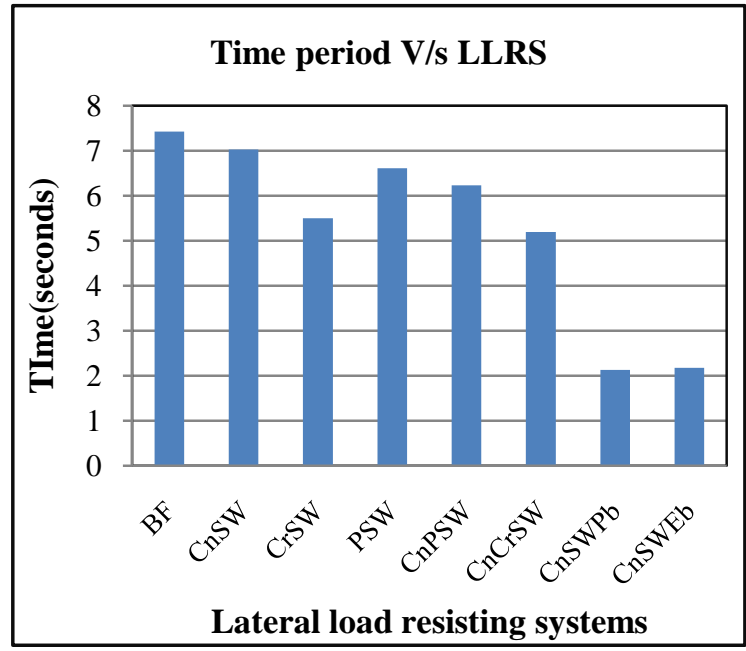

Figure 9: Time Period V/s LLRS

From Fig it is clear that the time period for bare frame building is too high when compared to building with lateral load resisting system. It indicates that the time period for flat slab building with perimeter beams has less time period when compared to all other models. Since the mass and stiffness of the building increases, it is effective in resisting the lateral forces which helps in reducing the time period.

\section{Base Shear}

The results of base shear in X-direction and Y-direction for time history analysis of various lateral load resisting systems are presented in and respectively.

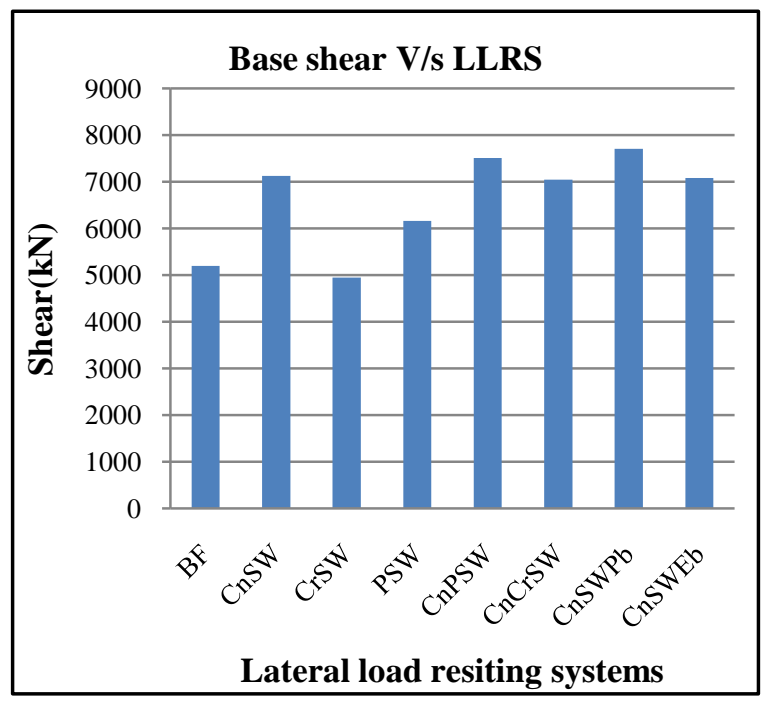

Figure 10: Base Shear in X direction V/s LLRS 


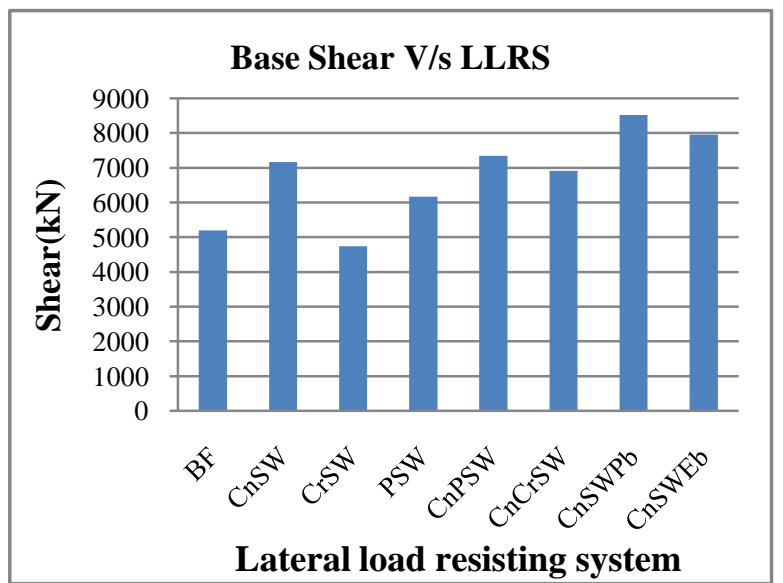

Figure 11: Base Shear in Y direction V/s LLRS

The average increase in base shear is about $48 \%$ and $36 \%$ for $\mathrm{CnSWPb}$ and $\mathrm{CnSWEb}$ respectively as compared to bare frame. This is due to the increase mass of the structure the base shear also increases.

Similarly the increase in base shear is about $63 \%$ and 53\% for $\mathrm{CnSWPb}$ and $\mathrm{CnSWEb}$ respectively as compared to bare frame. The increase in lateral force at the base of structure in $\mathrm{Y}$ direction when compared to $\mathrm{Y}$ direction base shear values may be due to the presence of channel shaped shear wall at centre of the building.

\section{CONCLUSION}

The following conclusion are drawn from the present study

- The reduction in top storey displacement for flat slab building with centre shear wall and perimeter beams is about $74 \%$ when compared to bare frame. Hence the building with centre shear wall and perimeter beams is effective in reducing the lateral displacement.

- The reduction in storey drift for flat slab building with centre shear wall and perimeter beams is about $83 \%$ when compared to bare frame. Hence the building with perimeter beams and centre shear wall effectively counteract the seismic forces and reduce the storey drift.

- The time period for flat slab building without any LLRS is comparatively more than other buildings. The considerably reduction in time period is found for corner shear wall, perimeter beams and bracing load resisting system.

- The natural time period for flat slab building with perimeter beams and centre shear wall is less amongst all lateral load resisting systems.

- There is increase in base shear for flat slab building with perimeter beam and centre shear wall.

- Among all the flat slab buildings with different LLRS the flat slab building with perimeter beam and centre shear wall shows better performance against seismic forces when compared to bare frame.

- Lateral load resisting system with bracing shows better performance over the LLRS with shear wall at various locations.

\section{REFERENCES}

[1] A. Walvekar and H.S. Jadhav, "Parametric Study of Flat Slab Building with and without Shear wall to Seismic Performance", International Journal of Research in Engineering and Technology, Vol. 4, No. 4, 2015.

[2] M. Vinod Kumar and G. Vaishali, "Comparative Study of Seismic Analysis between Conventional and Flat Slab with Drop and without Drop Framed Structures with Different Masonry Infill”, International Journal of Engineering Research and Technology, Vol. 3, No. 10, 2014.

[3] Lokesh Naik and K.S. Kulkarni, "Behaviour of Steel Braced(Mega-X and Normal-X) RCC multi-storeyed building under seismic condition", M. Tech thesis submitted at KLE Dr M.S Sheshgiri College of Engineering and Technology, 2015.

[4] Vinod Hosur, "Earthquake Resistant Design of Building Structures", Willey India private limited, Daryaganj, New Delhi, India, 2013.

[5] P. Agarwal and M. Shirkande, "Earthquake resistance design of structure", Prentice hall of India private limited, New Delhi, India, 2006.

[6] IS 1893:2002, "Indian Standard Criteria for Earthquake Resistance design of structures Part-1-General provisions and building", Bureau of Indian Standard, New Delhi, India.

[7] IS 456:2000, "Code of practice for plain and reinforced concrete", Bureau of Indian Standard, New Delhi, India.

[8] Pacific Earthquake Engineering Research Canter (PEER) ground motion earthquake database. 